\title{
Some Aspects of the Relations between the Catholic Church and the State in the Independent Latvia: the Concordat and the Preservation of Principles of Christian Ethics
}

\begin{abstract}
Pagal Latvijos Respublikos Konstituciją Bažnyčia yra atskira nuo valstybès. Praktikoje stebimas abiejų institucijų bendradarbiavimas. Bažnyčia turi ịtakos tam tikroms valstybès politikos sritims ir netgi dalyvauja politikoje tiesiogiai arba netiesiogiai. Straipsnyje apžvelgiamos Katalikų Bažnyčios ir valstybès tarpusavio bendradarbiavimo svarbiausios sritys dviem Latvijos istorijos laikotarpiais - pirmosios nepriklausomybès metais (daugiausia dèmesio skiriant 1920-1930 m.) ir po nepriklausomybès atgavimo (t. y. nuo $1991 \mathrm{~m}$.).

According to the Constitution of the Republic of Latvia "the Church shall be separate from the State". Still in practice both of these institutions cooperate. The Church has some influence on state policies, and even takes part in politics directly or indirectly. This article reflects the most important spheres of cooperation between the Catholic Church and the Latvian state and their results in two periods of existence of independent Latvia -1918 to 1940 (mainly concentrating on the 1920's) and after the independence was restored (i.e. since 1991).
\end{abstract}

\section{Introduction}

Research object - relations between the Latvian Catholic Church and the State in the independent Latvia: main spheres of cooperation and respective results.

The aim of the article is to elucidate main spheres of cooperation between the Latvian Catholic Church and the State, results of this cooperation for signing of the Concordat with Vatican and the preservation of Christian ethical principles.

Methodology - historical and cross-cultural comparative analysis.

Latvia as an independent state has existed for a relatively short period of time. The first period of independence lasted from 1918 until 1940. At the beginning of the World War II Latvia was first occupied by the USSR and then the Nazi Germany. The war was followed by the second occupation by the USSR. After nearly 50 years under atheistic soviet power, in 1991, with the fall of the USSR, Latvia regained its status of an independent state. Only during both periods of independence cooperation between the Church and the State was possible in many fields of importance to both the Church and the State. As during the first period of independence, today the Church in Latvia has a significant influence in the society. Expert in religious matters Ringolds Balodis concludes: it is a power that is invisible, but is much more efficient than that established by the written laws; it is a power over people's hearts and minds ${ }^{1}$. 
Quite a few discussions and arguments regarding the right model of relations between the Church and the State have been sparked by the words of Jesus: "Then pay Caesar what is due to Caesar, and pay God what is due to God" (Matthew 22: 21). The Latvian researcher of religion Valdis Tēraudkalns remarks that some have interpreted this text of the New Testament as a hint to the separation of worldly and religious spheres, while others have emphasised the absolute primacy of God, but there are also views that everything, including the Church, is a subject to the state power ${ }^{2}$. This issue still has not lost its importance. According to the Article 99 of the Constitution of the Republic of Latvia, the Church is separate from the state in Latvia ${ }^{3}$. Still, a model of cooperation of both institutions can be observed in practice. The Church has some influence on state policies, and it takes part in politics - either directly or indirectly. Directly - through its representatives in the institutions of power, and indirectly - during the public service, through its institutions of education, and mass media including the outlets owned by the Church. Christian confessions follow at least two motives for getting involved in politics: 1) they strive to ensure the inclusion of their ethical principles in the state legislation (e.g. the views on marriage, abortion, sexual minorities, euthanasia, etc.); 2) protection of their rights (e.g. acquisition or repossession of their property, the right to establish their own institutions of education, the right to solemnise a marriage, etc. $)^{4}$.

Although the Catholic Church is not the dominant Christian denomination in Latvia, it occupies a significant place among all denominations in the formation of public opinion, as well as in the dialogue between the State and the Church. According to the statistical data of the first independent Republic of Latvia (1918-1940) Catholics made approximately $23 \%$, while Lutherans $-55 \%$ of the total population of Latvia ${ }^{5}$. The Catholic faith was the dominating one (about $60 \%$ of the total population) in the eastern Latvia - Latgale. Today according to the data of sociological surveys about $23 \%$ of the population of Latvia count themselves as Catholics 6 . By the number of congregations the largest Christian denominations in modern-day Latvia rank as follows: Lutheran - 294, Catholic 250, Orthodox - 122, Baptist - 94, Old-Believers - 69 congregations ${ }^{7}$.

\section{The period of the Republic of Latvia (1918-1940): Changes in the Catholic Church and signing of the Concordat}

\section{Changes in the Latvian Catholic Church in 1920's}

Since the establishment of the independent Latvian state in 1918, the Latvian Catholic Church went through several following changes: 1) bishops of the Catholic Church were appointed from ethnic Latvians, previously clergy of Polish or Lithuanian descent was dominant. In 1920 a Latvian - Antonijs Springovičs - was ordained a bishop (and since 1923 - archbishop); 2) in 1918 the Diocese of Riga was re-established (since 1923 Archdiocese) with its administrative borders harmonised with those of the Latvian state ${ }^{8}$. The Diocese of Riga united not only Catholics of Latgale, but also those of other regions of Latvia (Kurzeme and Zemgale); 3) the Catholic Church became an active political subject. Catholic priests received the permission to participate in political parties 
and to become members of the Latvian parliament. With the support of the Catholic Church in 1920 a political party "Latgales kristigo Zemnieku savieniba" ('The Union of the Christian Peasants of Latgale'; later - "Latgales kristīgo Zemnieku un katolı partija" 'The Party of Christian Peasants and Catholics of Latgale') was established and led by Catholic priests. The party organised Catholic intelligentsia and peasantry for joint political activities. It also gained some success at the elections to the Latvian parliament (5-8 seats) and published a newspaper of the largest circulation and influence in Latgale titled "Latgolas Vōrds" (The Word of Latgale). "Latgales kristīgo Zemnieku savienība" not only defended the interests of the Catholic Church, but also addressed economic and social issues important for Latgale.

The political activity of the Catholic clergy was not a result of individual strive of some Catholic priests - activists, but also a duty imposed by the archbishop A. Springovičs?

It must be noted here, that in our day it is forbidden for Catholic priests to participate in politics directly, the Catholic Church also does not encourage the use of the word "Christian" in names of political parties ${ }^{10}$.

\section{The Concordat with Vatican}

In autumn 1919 canon Jāzeps Rancāns submitted a memorandum to Vatican. J. Rancāns characterised the situation of the Catholic Church in Latvia and pointed out the favourable attitude from the Latvian government that could have been used for the strengthening of the Catholic Church.

Within the Latvian state the legal status of the Catholic Church was fixed on 30 May 1922, when the Latvian government (the Prime Minister and Minister of Foreign Affairs of the day Zigfrids Anna Meierovics) signed the Concordat with Vatican (The Concordat between the Holy See and Lithuania was signed in 1927). The Latvian parliament ratified it on the $19^{\text {th }}$ of July of the same year.

It must be asked: why the Latvian government signed this Concordat when the population of the Catholic faith only constituted approximately $23 \%$ of the total population of Latvia of the 1920's? The negotiations regarding the signing of the Concordat were already initiated in the spring of 1920, but up until the signing of the Concordat there were heated discussions at the Latvian parliament. The Concordat was opposed not only by other Christian denominations, but also by many politicians - mainly the representatives of German and Russian minorities, and also a group of social democrats. Their main arguments were as follows: 1) the Concordat contradicted the Latvian Constitution, as the Church was separate from the state, i.e. the Concordat was "legally absurd" 2) the Concordat would put a single denomination - Catholic - in a privileged position, which was inadmissible for a democratic state ${ }^{12}$.

The Concordat was defended by both Catholic politicians of Latgale and members of the Latvian government, because: 1) the Concordat would provide an opportunity for the Catholic Church to be Latvian. It was emphasised at a parliament meeting that "the Catholic Church is a powerful organization, which could encourage the increase of national (Latvian) self-awareness in Latgale, where $60 \%$ of the population are Catholic, <...> 
where the population does not know its nationality, and in response to the question which nationality they belong to - say that they are Catholic. If they are told that "Catholic" is not a nationality, but rather religion, then they say that they are Polish"13. It must be explained here that as the result of polonisation and russification policies in Latgale countryside regions as late as 1920's the denominational identity (Catholic) prevailed over the national (Latvian); 2) the support from Vatican, i.e. that of the whole Catholic Church, and its international influence had contributed to the establishment of the Latvian independence and its international recognition de iure. At the decisive meeting of 19 July 1922 regarding the Concordat the Minister of Foreign Affairs Z. A. Meierovics said: "It is true, gentlemen, that economically we must sacrifice something, $\langle\ldots\rangle$ then we achieve a certain political goal. $<\ldots>$ The state must offer sacrifice every time, in order to achieve its strengthening." ${ }^{\prime 4}$

Although Z. A. Meierovics in his speech renounced the blame of the opponents that the government did not treat all denominations equally ${ }^{15}$, one must admit that the Concordat provided a number of privileges to the Latvian Catholic Church: 1) other Christian denominations in Latvia functioned in accordance with the regulations developed by the State Control and approved by the Ministry of the Interior, while the Catholic Church only followed the canon set by Vatican; 2) priests were dismissed from the military service, the institution of chaplain was introduced; 3 ) church buildings, seminary premises, bishop dwellings were exempt from taxation; 4) Catholic spiritual orders were permitted to operate; 5) according to the Concordat along with the establishment of the Riga Diocese and the Catholic theological seminary, the Catholic Church received a state support of 1 million Latvian roubles [2,000 lats - V. M. $]^{16}$.

The Concordat required that one of the church buildings belonging to the Lutheran Church would be transferred to the Catholic Church. The administration of the Catholic Church demanded Riga Dome or St. Peter's church, though later on received St. Jacob's church. Lutherans protested this. On 1 July 1922 the congregation of St. Jacob's Church sent a protest letter to the Latvian parliament, calling "not to hand over Latvia to the power of Rome, not to allow the shady actions of the Jesuits and not to vote for the Concordat with the Holy See" ${ }^{\prime 7}$. When the majority of the Parliament during Easter of 1923 voted for the law providing the transfer of St. Jacob's Church to Catholics the representatives of Riga German minority and part of Lutherans demanded a national referendum regarding the change of the church's ownership. Although only $1 / 5$ of those having the right of suffrage voted for the Lutheran proposal ${ }^{18}$, the transfer of St. Jacob's Church to Catholics beyond doubt deteriorated the relations between the Latvian Lutheran and Catholic Churches.

With the Concordat of 1922 the Catholic Church was the first of Latvian denominations to achieve a special status within the state. Many paragraphs of the Concordat were used by the Government for later regulations regarding the religious status of other denominations. ${ }^{19}$

After the occupation of Latvia in the summer of 1940 the Soviet government on the $13^{\text {th }}$ of August informed Vatican about the termination of diplomatic relations and on the $24^{\text {th }}$ of August expelled Pope's nuncio from Riga. It must be reminded here that the Holy See has never recognised the incorporation of the Baltic States into the USSR and has always considered the diplomatic relations with these countries being only temporarily suspended. ${ }^{20}$ 


\section{Cooperation after the renewal of Latvia's independence (since 1991)}

\section{The Concordat of 2002}

In autumn 2002 in Rome in solemn atmosphere the Concordat between the Republic of Latvia and Vatican was signed. Latvia was represented by its Prime Minister Andris Bērzinšs, cardinal of the Catholic Church Jānis Pujats, bishop of Liepāja diocese Vilhelms Lapelis, Latvian ambassador to Vatican Atis Sjanītis, Minister of Justice Ingrīda Labucka. ${ }^{21}$

Essentially this document only renewed the agreement of 1922, superseding it with the content appropriate for the new era. So, for instance, the grant of the status of a sacred site/shrine to Aglona in the Concordat was viewed as logical and necessary recognition of a century-old tradition. ${ }^{22}$

Latvia renewed its diplomatic relations with Vatican in 1991. At the same time the idea of the necessity to renew the Concordat was born. Nevertheless, only in 1999 at a regular meeting of the Latvian and Vatican work group it was decided to approve the final version of the Concordat and to submit it for further consideration in the Latvian government and parliament. In the process of preparation of the agreement it was discussed for more than two years in the press, on television and other mass media.

The Concordat was opposed by other Latvian Christian denominations, especially the Baptists. In 1996 Bishop of the Union of Baptist Congregations Andrejs Šterns on behalf of Baptists formulated several objections to the signing of the Concordat: 1) the principle of separation of the Church and the State stipulated in the Constitution would be broken; 2) a denomination, only uniting about $1 / 5$ of Latvian population, would receive a more favourable status; 3 ) the established existing unity and balance between the Latvian traditional denominations would be broken; 4) the tax payers' money in Latvia would be allocated to the support of a single Church. ${ }^{23}$

Still it must be kept in mind that the Concordat classifies not as an agreement between the Latvian Catholic Church and the State, but rather as an international agreement. As the main goal of Latvian foreign policy was the integration into the EU and strengthening of its positions internationally, Vatican as an influential political force provided good support in international relations ${ }^{24}$. Therefore, notwithstanding diverse objections, the Latvian parliament at its meeting of 12 September 2002 passed the Law on the Agreement between the Republic of Latvia and the Holy See. 58 members of the Parliament voted in favour of the Law, no one voted against, while 7 abstained ${ }^{25}$.

\section{Agreements with the State regarding the status of sacred site of Aglona}

Aglona became the centre of Latvian Catholicism already in 1920's. In 1920 the Catholic Theological seminary was opened in the monastery of Aglona church, and until 1924 Aglona was the residence of Rìga Archdiocese bishop A. Springovičs.

In our day Aglona is one of the most recognisable pilgrimage sites in Eastern Europe. Traditionally on the $15^{\text {th }}$ of August the Assumption of Mary is celebrated at Aglona basilica, quite frequently attended by more than 100,000 pilgrims. 
In 1991 it was proposed to create a centre of Christian culture in Aglona. This was followed by the decree of the Latvian government regarding the creation of a work group dealing with the restoration of the complex of Aglona basilica and coordination of the restoration work. Both state and private funds were allocated for the reconstruction work. For instance, the Pope donated 100,000 US dollars for this purpose. ${ }^{26}$

The reconstruction was accomplished expecting the visit of the Pope, as in 1990 the Pope John Paul II had expressed his wish to visit Aglona. The Pope's visit took place in September 1993. It was a great event not only for Catholics, but also the whole Latvian state: firstly, because of the authority of Vatican on the world scale, and secondly, because of the Pope's expressed support for the independence of the Baltic States.

In 1995 an agreement between the Catholic Church and the Latvian state was signed; the principles of this agreement were determined in the Law on sacred site/shrine of international scale in Aglona. The Law recognised the Aglona sacred site as part of Latvian cultural and historical heritage, i.e. a cultural monument and a site of religious pilgrimage. In accordance with the Law, Aglona sacred site can only be used for events of religious and spiritual character that are determined by the administration of the Catholic Church in Latvia. The Law states that the maintenance costs of Aglona sacred site related to national events can be covered from the state budget. Costs related to medical services, enforcement of road traffic and public order during national level events at Aglona sacred site and in its area of protection may also be covered from the state budget ${ }^{27}$. The issue of financing of events at Aglona sacred site has been and still is sensitive. For instance, as late as at the end of the 1990's the Latvian state and the administration of the Catholic Church were still discussing the funding for the reconstruction of Aglona basilica carried out in preparation for the visit of the Pope ${ }^{28}$. On the other hand, in 2006 state budget 1,000,000 Lats were allocated for repairs of the Aglona basilica and development of the sacred site's infrastructure ${ }^{29}$.

\section{Discussions regarding the subject of religion in state schools}

Since the early 1990's the discussion about the introduction of the subject of religion in state schools lasted for several years in Latvia. The discussion basically considered the content of such subject. Shall it include a fragmented world-view of world religions or shall it be only limited to Christian teachings? The leaders of Latvia's largest Christian denominations, especially Catholics, defended the idea of authentic teaching of their denomination's religious views.

In September 1990 the Law on religious organizations was passed. The Clause 6 of the Law "Religious organizations and education" stipulates that: 1) everyone has the right to study religion both individually and along with others in educational institutions of religious organizations; 2) state and municipal schools may teach Christian religion to individuals who have stated their wish to study it in written; 3) the subject of Christian religions shall be taught by teachers from Evangelical Lutheran, Roman Catholic, Orthodox, Old-Believer and Baptist denominations according to a study programme approved by the Ministry of Education and Science, on the condition that there are at least 10 pupils at 
the particular school wishing to learn the teachings of the respective Christian denomination. The teachers are to be selected by the administration of the denomination and then attested by the Ministry of Education and Science; 4) teaching of Christian religion and ethics is funded by the state budget. ${ }^{30}$

Nevertheless, the polemics and discussions regarding the character of the religious education - namely, shall it be denominational or interdenominational - continued until the end of the 1990's. In 1998 the opponents of denominational religious education expressed their view in an open letter to the highest state officials that in modern multicultural society most of the people encounter diverse world-views, therefore an individual must be aware of the diversity of religious views, and the school must not be turned into a battleground for rivalries of different denominations. ${ }^{31}$

Administration of the Catholic Church, represented by Cardinal J. Pujats, citing the Latvian Constitution which stipulates the separation of the Church and the State, characterised the opinion of the opponents of denominational religious education as an interference with the internal affairs of the Church ${ }^{32}$. This was followed by a letter of four denominations (Catholic, Lutheran, Orthodox and Old-Believer) to the Members of the Parliament emphasising that their stance on education issues can only be represented by the legitimate administration of the respective denomination ${ }^{33}$.

It must be noted here that the status of Catholic religious education was also strengthened by the Concordat of 2002. The Clause 15 of the Concordat stipulates that Catholic religious education can only be taught based on the programme approved by the Latvian Conference of Bishops, when the programme is accepted by the Ministry of Education and Science, and according to the procedure determined by the law, it can only be taught by qualified teachers who have received a certificate of qualification issued by the Latvian Conference of Bishops. In case this certificate is revoked, the respective teacher loses the right to teach Catholic religious education. In addition to that, the Clause 17 of the Concordat requires that Catholic religious education in educational institutions must be taught with sufficient academic and doctrinal competence seeking to encourage ecumenical spirit, mutual respect among different religious denominations and equality. ${ }^{34}$

In 2004 after lengthy discussions a curriculum of Christian education for the first three years of elementary school was developed in Latvia as an interdenominational study subject. The aim of this subject, as formulated in the curriculum, is to encourage the spiritual and moral development of pupils and to develop their ability to exist in a changing world, revealing the opportunities for the creation of personal relationship with God and life-assuring attitude towards the society ${ }^{35}$. Teachers of religious education for Latgale region study at Rēzeknes Augstskola (Rēzekne Higher Education Institution; study programme "Religion pedagogy") with the support of Rēzekne - Aglona diocese.

\section{Efforts of the Church administration in the formation of public opinion and politicians' attitude towards sexual minorities and abortion}

In 2004 in the context of globalisation and European integration, the National Programme for Promotion of Tolerance was approved in Latvia, envisaging the creation of tolerant 
Latvian society and the eradication of intolerance ${ }^{36}$. This Programme was planned for five years - until 2009. At the beginning of 2009 a work group under the leadership of the Special Task Ministry in Issues of Social Integration [the Ministry as an independent institution was closed on 1 January 2009 - V. M.] prepared a new programme for the promotion of tolerance for the period 2009-2013.

But before the consideration by the Government the content of the programme was changed. The main reason for that were the events of the parade of sexual minorities "Rigas Praids", which was held since the summer of 2005. These events resulted in significant reaction of the Latvian society - from support or neutral stance to harsh opposition. Negative attitude towards the parade of sexual minorities in Riga was expressed by both representatives of the Church and members of the Government, as well as several public figures. There were several incidents of open hatred towards homosexuals. Therefore, the Latvian government suggested including sexual minorities in the Tolerance programme as a specific marginal group. Still in spring of 2008, after Special Task Minister in Issues of Social Integration Oskars Kastēns' meeting with religious leaders, including Catholic archbishop at the time cardinal J. Pujats and leader of the Evangelical Lutheran Church archbishop Jānis Vanags, words "sexual orientation" were withdrawn from the programme. It was also proposed to delete from the programme the text listing bases of discrimination, namely - race, skin colour, ethnic origins, language, sex, age, religious beliefs, social and welfare situation, political and other views, disability and sexual orientation $^{37}$. According to the opinion of the representatives of the Church, inclusion of sexual orientation in this list would have polarized Latvia. Therefore, because of a single social group - sexual minorities - the Government decided not to list any marginal groups in the explanation of the bases of discrimination ${ }^{38}$. The representatives of the Government explained that the Church represented a large proportion of society, therefore the State had to consult the Church regarding issues of tolerance ${ }^{39}$.

Cardinal of the Catholic Church J. Pujats considered the new version of the Tolerance programme as one of the greatest achievements in the dialogue of the Church and the Latvian state: We managed to achieve that homosexuality could not gain any legal power; it was left outside the legislation ${ }^{40}$.

Current Latvian Catholic archbishop Zbigṇevs Stankevičs thanked everybody who opposed homosexuality and called the society to do it without aggression and not offending personal dignity ${ }^{41}$.

On the issue of abortion archbishop Z. Stankevičs has promised to support the amendments to the Law on Sexual and Reproductive Health. In June 2012 several female members of the Latvian parliament suggested amendments to the Law on Sexual and Reproductive Health requiring the doctor to inform women about processes inside their bodies before performing an abortion (showing the ultrasonography image or asking to listen to child's heart beat). ${ }^{42}$ Still at the moment being this proposal has not been supported by the majority of the Members of the Parliament.

Archbishop of the Catholic Church emphasizes that secular society could take note of, for example, a reference to the Latvian Civil Law, where a not yet born child is provided with the right to inheritance. Thus, this child has also the right to live ${ }^{43}$. 
The administration of the Latvian Catholic Church believes that secular society must be convinced to oppose the abortion first, and then proposals for amendments to the Law on Sexual and Reproductive Health can be submitted.

\section{Conclusions}

In summary, we can draw a conclusion that the Latvian Catholic Church and the State collaborate on several issues of importance for both religious people and secular society. The Catholic Church also participates in politics. Today the participation of the Latvian Catholic Church in politics is indirect, i.e. the Church can influence the public opinion and does so, which is in fact participation in politics. The Catholic Church does not attempt to gain power, but it is capable (at least to some extent) to have influence on governmental institutions so that they would take into account Catholic ethical principles, as well as rights and interests of the Catholic Church.

The most important achievement of the collaboration of the Catholic Church and the State is the signing of the Concordat of 1922 and 2002 that strengthened the legal status of the Catholic Church, also providing it with some privileges. The Concordats are also of political importance to the Latvian state, given the international influence of Vatican and its support for the independence of the Latvian state.

Unlike the period of the first independent Latvian state (1918-1940), after regaining independence (since 1991) issues of the preservation of Christian ethical principles in the society have gained significant importance in the relations of the Church and the State.

One must admit that the gain from the collaboration of the Catholic Church and governmental institutions is mutual. It was for a reason that the Latvian press featured the following expression in an article published before the parliamentary elections: Dead is the politician, who $<\ldots>$ does not intend to reckon with the votes of the faithful ${ }^{44}$.

\section{REFERENCES}

Balodis R. Valsts un Baznīca. Rīga: Nordik. 2000. P. 350.

2 Tèraudkalns V. Kristus un Cēzars. Rīga: Zinātne. 2010. P. 7.

3 Latvijas Republikas Satversme // http://www.likumi.lv/doc.php?id=57980. 20130820.

4 Balodis. Ibid. P. 353-354.

5 Skujenieks M. Latvija (1918-1938). Statistikas atlass. Rīga: Valsts statistikas pārvalde. 1938. P. 12.

6 Svētā Krēsla un Latvijas attiecību vēsture // http://www.catholic.lv/main.php?parent=2728. 20130414.

7 Politiskā dzīve un reliǵija // http://data.csb.gov.lv/DATABASE/visp/Ikgadējie\%20statistikas\%20 dati/Politiskā\%20dzīve\%20un\%20relig̣ija/Politiskā\%20dzìve\%20un\%20reliğija.asp. 20130414.

8 Strods H. Latvijas Katoḷu Baznīcas vēsture (1075-1995). Rīga: v/u Poligrāfists. 1996. P. 243.

9 Apkārtraksts katoḷu baznīckungiem // Latvijas Valsts vēstures arhīvs (LVVA). F. 5016. Apr. 1. L. 47.

10 Balodis. Ibid. P. 350.

11 Latvijas Republikas Satversmes Sapulces stenogrammas (LRSSS). 5. ses., 2833. 2848.

12 Ibid. 2838.

13 Ibid. 2848-2849.

14 Ibid. 2853. 
15 Ibid. 2839.

16 Strods. Ibid. P. 243.

17 Cakuls J. Latvijas Romas Katoḷu Baznīcas vēstures materiāli: 20. gadsimts. Rīga: Rīgas metropolijas kūrija. 2001. P. 704.

18 Ibid. P. 705.

19 Balevics Z. Katolicisms Latvijas sociālpolitiskajā vēsturē. Rīga: Zinātne. 1978. P. 114.

20 Svētā Krēsla un Latvijas attiecību vēsture. Ibid.

21 Likums par Latvijas Republikas un Svētā Krēsla līgumu // http://www.saeima.lv/steno/2002/st_1209/ st1209.htm. 20121204.

22 Latvijas Republikas un Svētā Krēsla līgums // http://www.catholic.lv/likumskonkordaats.htm. 20121127.

23 Balodis. Ibid. 544.

24 Ibid.

25 Latvijas Republikas un Svētā Krēsla līgums. Ibid.

26 Zeile P. Latgales kultūras vēsture. Rēzekne: LKCI. 2006. P. 655.

27 Likums par starptautiskas nozīmes svētvietu Aglonā // http://www.likumi.lv/doc.php?id=273888\& from=off. 20130112.

28 Balodis. Ibid. P. 543.

29 Grozījumi likumā „Par valsts budžetu 2006. gadam” 17. Pielikums // http://www.fm.gov.lv/ budžets/2006g/p17.doc. 20121203.

30 Reliğisko organizāciju likums // http://www.tm.gov.lv/lv/ministrija/iestades/religjiskie/Rel_org_ likums.doc. 20121127.

31 Balodis. Ibid. P. 257.

32 Solis. 1998 16-22 10.

33 Balodis. Ibid. P. 258.

34 Latvijas Republikas un Svētā Krēsla līgums. Ibid.

35 Kristīgās mācības programma 1.-3. klasei // http://www.isec.gov.lv/pedagogiem/program/pamskol/ prog.shtml?KRIST1_3. 20121126.

36 Nacionālā programma iecietības veicināšanai // http://www.intrecija.gov.lv/doc_upl/programmaiecietiba.pdf. 20121126.

37 Ibid.

38 Zankovska-Odiņa S. Plastilinna iecietība // http://www.politika.lv/temas/16723. 20120915.

39 Dzērve L. NVO krasi iebilst, kā reliǵisko līderu ietekmē koriḡēta Iecietības programma // http:// www.diena.lv/lat/politics/sabiedriba/baznica_un_valsts?comments=3. 20120915.

40 Ibid.

41 Arhibīskaps Stankevičs pateicas praida pretiniekiem // http://puaro.lv/lv/puaro/arhibiskapsstankevics-pateicas-praida-pretiniekiem. 20130411.

42 Katoḷu baznīca gatava pārliecināt aborta aizstāvjus // http://nra.lv/latvija/31988-katolu-baznicagatava-parliecinat-aborta-aizstavjus.htm. 20130411.

43 Ibid.

44 Nedēḷa Tev. 19950515.

\section{LITERATURE AND SOURCES}

1. Apkārtraksts katoḷu baznīckungiem // Latvijas Valsts vēstures arhīvs (LVVA). F. 5016. Apr. 1. L. 47.

2. Arhibīskaps Stankevičs pateicas praida pretiniekiem // http://puaro.lv/lv/puaro/arhibiskapsstankevics-pateicas-praida-pretiniekiem. 20130411. 
3. Balevics Z. Katolicisms Latvijas sociālpolitiskajā vēsturē. Rīga: Zinātne. 1978.

4. Balodis R. Valsts un Baznīca. Rīga: Nordik. 2000.

5. Cakuls J. Latvijas Romas Katoḷu Baznīcas vēstures materiāli: 20. gadsimts. Rīga: Rīgas metropolijas kūrija. 2001.

6. Dzērve L. NVO krasi iebilst, kā reliǵisko līderu ietekmē korig̣ēta Iecietības programma // http:// www.diena.lv/lat/politics/sabiedriba/baznica_un_valsts?comments=3. 20120915.

7. Grozījumi likumā „Par valsts budžetu 2006. gadam” 17. Pielikums // http://www.fm.gov.lv/ budžets/2006g/p17.doc. 20121203.

8. Katoḷu baznīca gatava pārliecināt aborta aizstāvjus // http://nra.lv/latvija/31988-katolu-baznicagatava-parliecinat-aborta-aizstavjus.htm. 20130411.

9. Kristīgās mācības programma 1.-3. klasei // http://www.isec.gov.lv/pedagogiem/program/pamskol/ prog.shtml?KRIST1_3. 20121126.

10. Latvijas Republikas Satversme // http://www.likumi.lv/doc.php?id=57980. 20130820.

11. Latvijas Republikas Satversmes Sapulces stenogrammas (LRSSS). 5. ses., 2833., 2839., 2848., 2849. , 2853.

12. Latvijas Republikas un Svētā Krēsla līgums // http://www.catholic.lv/likumskonkordaats.htm. 20121127

13. Likums par Latvijas Republikas un Svētā Krēsla līgumu // http://www.saeima.lv/steno/2002/st_1209/ st1209.htm. 20121204.

14. Likums par starptautiskas nozīmes svētvietu Aglonā // http://www.likumi.lv/doc.php?id=273888\& from=off. 20130112.

15. Nacionālā programma iecietības veicināšanai // http://www.intrecija.gov.lv/doc_upl/programmaiecietiba.pdf. 20121126.

16. Nedēla Tev. 19950515.

17. Politiskā dzīve un reliğija // http://data.csb.gov.lv/DATABASE/visp/Ikgadējie\%20statistikas\%20 dati/Politiskā\%20dzīve\%20un\%20reliğija/Politiskā\%20dzīve\%20un\%20reliǵija.asp. 20130414.

18. Reliğisko organizāciju likums // http://www.tm.gov.lv/lv/ministrija/iestades/religjiskie/Rel_org_ likums.doc. 20121127.

19. Skujenieks M. Latvija (1918-1938). Statistikas atlass. Rīga: Valsts statistikas pārvalde. 1938.

20. Solis. 1998 16-22 10.

21. Strods H. Latvijas Katoḷu Baznīcas vēsture (1075-1995). Rīga: v/u Poligrāfists. 1996.

22. Svētā Krēsla un Latvijas attiecību vēsture // http://www.catholic.lv/main.php?parent=2728. 20130414 .

23. Tèraudkalns V. Kristus un Cēzars. Rīga: Zinātne. 2010.

24. Zankovska-Odiña S. Plastilīna iecietība // http://www.politika.lv/temas/16723. 20120915.

25. Zeile P. Latgales kultūras vēsture. Rēzekne: LKCI. 2006.

Gauta: 20130930

Parengta spaudai: 20140224

Vladislavs MALAHOVSKIS

\section{KATALIKỤ BAŽNYČIOS IR VALSTYBĖS SANTYKIỤ NEPRIKLAUSOMOJE LATVIJOJE KAI KURIE ASPEKTAI: KONKORDATAS IR KRIKŠČIONIŠKOSIOS ETIKOS PRINCIPŲ IŠSAUGOJIMAS}

S a n trauka

Latvija kaip nepriklausoma valstybė gyvavo palyginti neilgai. Pirmasis nepriklausomybès laikotarpis tęsėsi nuo 1918 m. iki 1940 m. Antrojo pasaulinio karo pradžioje Latvija iš pradžių buvo okupuota Sovietų Sąjungos, vèliau - nacistinès Vokietijos. Po karo Sovietų Sąjunga okupavo Latviją antrą kartą. Po beveik $50 \mathrm{~m}$. 
trukusio ateistinès valdžios valdymo, 1991 m., griūnant Sovietų Sąungai, Latvija atgavo nepriklausomos valstybès statusą.

Straipsnio tikslas - apžvelgti Latvijos Katalikų Bažnyčios ir valstybės bendradarbiavimo pagrindines sritis, šio bendradarbiavimo įtaką pasirašant konkordatą su Vatikanu ir saugant krikščioniškosios etikos principus.

Pagal Latvijos Respublikos Konstituciją Bažnyčia yra atskira nuo valstybės. Tačiau iš tiesų abi institucijos bendradarbiauja, o Bažnyčia tiesiogiai ir netiesiogiai dalyvauja politikoje. Tiesiogiai - per savo atstovus valdžios ịstaigose, netiesiogiai - per mišias, švietimo įstaigas, žiniasklaidą, įskaitant ir Bažnyčios leidžiamus periodinius leidinius.

Tyrimas atskleidžia, kad Latvijai atgavus nepriklausomybę Katalikų Bažnyčia išgyveno keletą pokyčių:

1. 1918 m. atkurta Rygos vyskupija (nuo 1923 m. - arkivyskupija), ji apėmė Kuržemės, Žiemgalos ir Latgalos regionus;

2. Pirmieji Latvijos vyskupai buvo lenkų arba lietuvių kilmès, vèliau jais buvo skiriami latviai. $1920 \mathrm{~m}$. Latvijos vyskupu ǐšventintas Antonijs Springovičs (nuo 1923 m. - arkivyskupas);

3. Latvijai atgavus nepriklausomybę Katalikų Bažnyčia tapo aktyvi politikoje. Katalikų kunigai aktyviai reiškèsi politinèse partijose, o keletas jų net išrinkti į Latvijos parlamentą.

Vienas svarbiausių Katalikų Bažnyčios pasiekimų Latvijoje - bendradarbiavimas su Latvijos Vyriausybe, kai 1922 m. pasirašytas konkordatas tarp Latvijos Respublikos ir Vatikano. Konkordatas numate privilegijas Katalikų Bažnyčiai:

a) visos Latvijoje veikiančios krikščionių Bažnyčios, išskyrus Katalikų Bažnyčią, veikė pagal Latvijos valstybès ir Latvijos vidaus reikalų ministerijos parengtas taisykles. Katalikų Bažnyčia Latvijoje veikè pagal Vatikano nustatytus kanonus;

b) Krašto apsaugos ministerijos institucijose ịvesta kapeliono pareigybè, katalikų kunigai atleisti nuo privalomos karinès tarnybos;

c) Katalikų Bažnyčia atleista nuo mokesčių valstybei;

d) katalikams suteikta teisė be licencijų vykdyti įvairius tarptautinius ekonominius sandorius;

e) katalikams iš valstybès bei kitų konfesijų buvo grąžinti jiems priklausę pastatai.

Tuo metu Latvijoje daug kam kilo klausimas, kodèl Latvijos parlamentas ir Vyriausybė sudarè konkordatą su Vatikanu, jei Latvijoje liuteronų buvo 55 \%, o katalikų tik 23 \%. Svarstyta, ar tai nepablogins Liuteronų ir Katalikų Bažnyčių tarpusavio santykių. Vis dėlto Vatikano ịtaka tarptautineje politikoje ir politinė bei dvasinė parama turejjo daug reikšmės pripažistant Latvijos nepriklausomybę de jure tarptautiniu mastu.

Šiandien Katalikų Bažnyčia Latvijos politikoje dalyvauja netiesiogiai. Ji daro ịtaką formuojant viešąją nuomonę. Katalikų Bažnyčios ir Latvijos valstybės bendradarbiavimą geriausiai liudija šie faktai:

1. Bendradarbiavimas rengiantis popiežiaus Jono Pauliaus II vizitui Latvijoje 1993 m. ir priimant Jo Šventenybę - šis ịvykis buvo svarbus ne tik Katalikų Bažnyčiai Latvijoje, bet ir visai valstybei.

2. Agluonos šventovès statuso įteisinimas tarptautiniu mastu.

3. 2002 m. Romoje naujai pasirašytas konkordatas tarp Latvijos Respublikos (kartu ir Bažnyčios) ir Vatikano. Tai ne tik Katalikų Bažnyčios Latvijoje ir Latvijos valstybès susitarimas, bet ir tarptautinė sutartis.

4. Katalikų Bažnyčios Latvijoje aktyvus dalyvavimas ekumeninejje religinio švietimo veikloje šiandien:

a) vidurinèse mokyklose tikybos pamokos priskiriamos prie laisvai pasirenkamų dalykų;

b) Katalikų Bažnyčia Latvijoje išsako savo poziciją dèl seksualinių mažumų protegavimo ir abortų.

Latvijos valdžios institucijos ir politikai, kurdami politiką, atsižvelgia ị Katalikų Bažnyčios poreikius ir interesus.

PAGRINDINIAI ŽODŽIAI: Latvija, Romos Katalikų Bažnyčia, konkordatas, valstybė, santykiai.

KEY WORDS: Latvia, the Roman Catholic Church, the Concordat, the State, relationship.

Vladislavs MALAHOVSKIS - Rėzeknès universiteto Regioninių studijų instituto docentas. El. paštas vladism@inbox.lv. Tel. +37129140983.

Vladislavs MALAHOVSKIS - associate professor, Research Institute for Regional Studies, Rezekne University, Latvia. E-mail: vladism@inbox.lv. Phone number: +37129140983. 